\title{
Comparative Research on Library Law in China, the United States, Korea and Japan
}

\author{
Wenyan Cheng, Xi Zhang, Honglan Zheng \\ Library of Yanshan University, Qinhuangdao, China \\ Email: cwy@ysu.edu.cn, zhangxi@ysu.edu.cn, zhl@ysu.edu.cn
}

How to cite this paper: Cheng, W.Y., Zhang, X. and Zheng, H.L. (2019) Comparative Research on Library Law in China, the United States, Korea and Japan. Open Access Library Journal, 6: e5333. https://doi.org/10.4236/oalib.1105333

Received: March 12, 2019

Accepted: March 24, 2019

Published: March 27, 2019

Copyright $\odot 2019$ by author(s) and Open Access Library Inc.

This work is licensed under the Creative Commons Attribution International License (CC BY 4.0).

http://creativecommons.org/licenses/by/4.0/

\section{(c) (i) Open Access}

\begin{abstract}
This paper makes a comparative analysis of the Public Library Law of the United States, Japan, South Korea and China. The main comparison parts include: legislation process, legislative models, law revision, comprehensive content and detailed regulations. Through the comparative study, the paper sums up some highlights on library law of the United States, Japan and South Korea from the simultaneous development of library law and library-related laws, legislates first, and then continues to improve, and guarantee the financial resources of the library and detailed legislative content, aiming at providing some references for the improvement of Chinese library law.
\end{abstract}

\section{Subject Areas}

Library, Intelligence and Philology

\section{Keywords}

Comparative Research, Library Law, China, the United States, Japan, South Korea

\section{Introduction}

At present, about 60 countries have promulgated more than 250 library laws and regulations [1]. The United States is one of the countries with the most developed library undertakings in the world. The library law of Japan promulgated in April 1950 is a law regulating public library and private library, which plays a role of "basic law" in the library legal system of Japan. The public library law of China was adopted at the 30th session of the standing committee of the 12th National People's Congress of the People's Republic of China on Nov 4, 2017. The law takes effect on Jan 1, 2018. This paper first makes a comparative analysis of the public library law of the United States, the library law of Japan, the public li- 
brary law of the republic of Korea and the public library law of the republic of China from legislation process, legislative models, law revision, comprehensive content and detailed regulations, and then points out the highlights on library laws, gives the suggestions on china's library law.

\section{The Legislative Situation of Public Library Law in China, the United States, Japan and Korea}

\subsection{Comparison of Legislation Process}

The legislative process of libraries in China [2] [3], the U.S. [4], Japan [5] and South Korea [6] is as follows (Table 1).

Table 1. Comparison of legislative process.

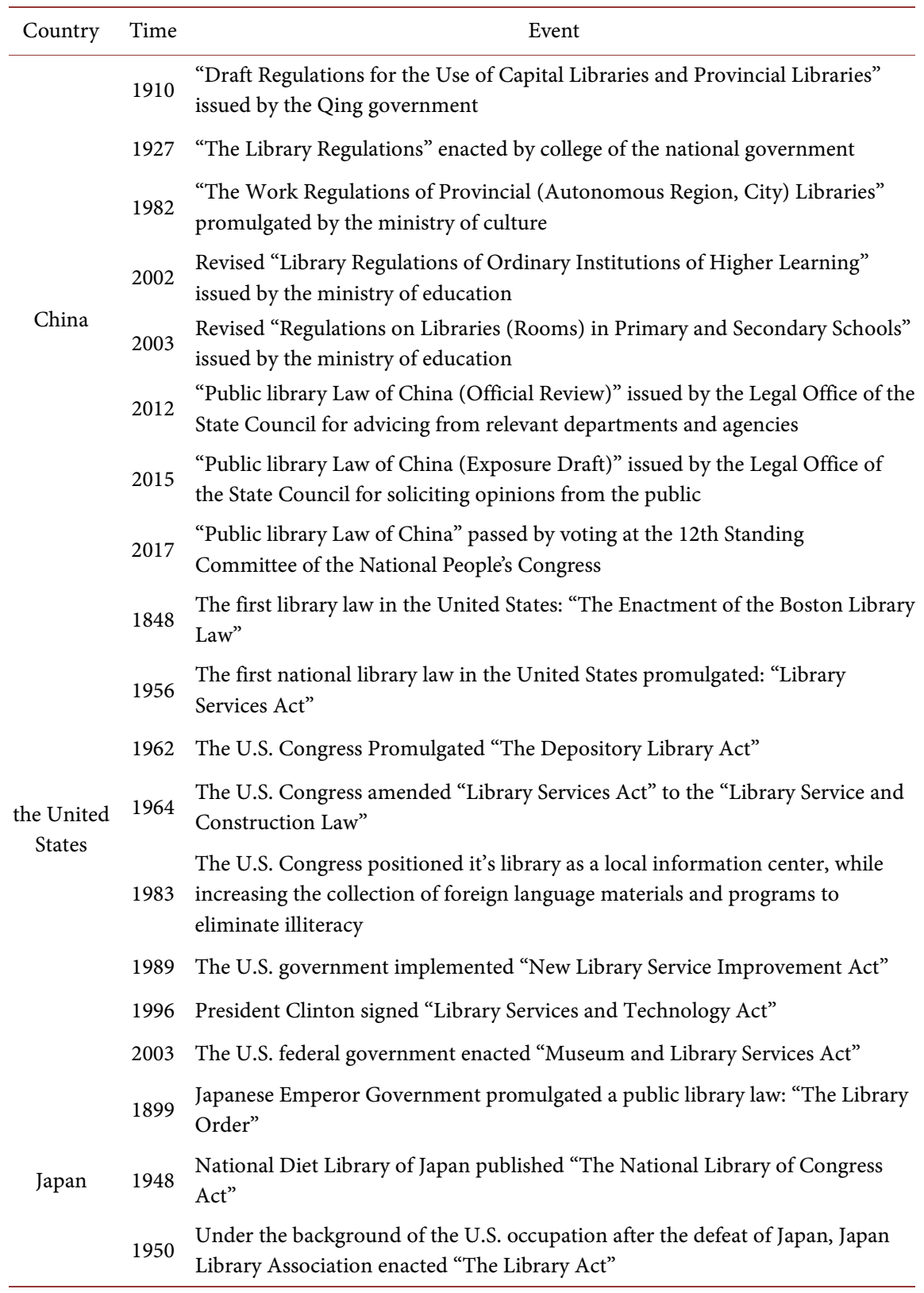




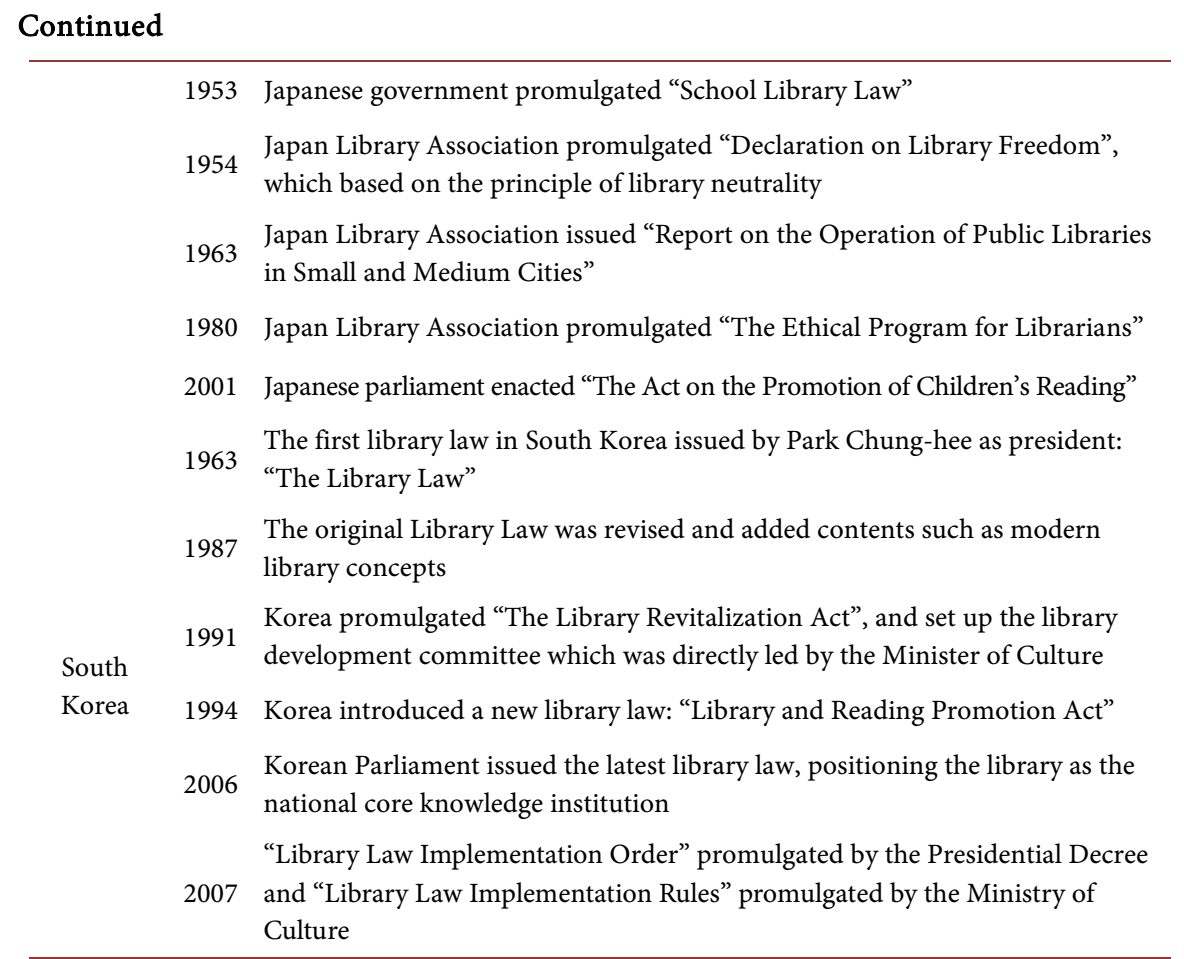

\subsection{Comparison of Legislative Models}

The comparison of legislative models on library laws in China, the U.S., Japan and South Korea is as follows.

From Table 2, it can be seen that the legislative models of the four countries are different, which reflects the status quo of the legalization process of libraries in various countries: State library legislation of the U.S. precedes federal library legislation, and its industry library legislation have also played very important roles, so the U.S. library laws are relatively perfect. Japan has experienced the continuous revision of the development on "Library Act" and "Library Law" in the form of separate legislation, and supplements by horizontal industry norms and other library related laws, and builds a relatively complete and mature system. Although South Korea library legislative work started earlier, only the national library law was enacted due to its limited land area and population. China is still a developing country; the comprehensive strength still needs to be improved. Therefore, its national library law is aimed at public libraries, and implemented late.

\subsection{Law Revision}

The U.S. library law has a history of more than 100 years, and forms a revision cycle of "development-execution-correction-supplement". After continuous revision and supplement, it has gradually formed a relatively complete content system. Library law at the federal level in the U.S. focuses on the field of public libraries, and state-level library laws often involve more types of libraries because they cover all the library-related legal provisions of the state. Due to the change or promulgation of the library-related laws, when Japan and South Korea are in 
Table 2. Comparison of legislative models.

\begin{tabular}{cc}
\hline Country & Legislative models \\
\hline China & National special law + Local regulations \\
the U.S. & State library law + Federal library law + Industry legislation \\
Japan & National special laws + Industry legislation + Library-related laws \\
South Korea & National law + Library-related laws \\
\hline
\end{tabular}

the process of implementing the library law, they not only promulgated and formulated the relevant law enforcement orders and rules, but also revised the library law for many times.

Due to the immense power of the Japanese government over legislative enactment and revision, there exist narrow possibilities for legislative revision with the result that the structure and characteristics of library legislation within Japan are nearly the same today as they were at the time of their enactment. In Korea, where the National Assembly has vast powers over the enactment and revision of legislation, revisions have been carried out on a large scale, resulting in numerous changes of structure and characteristics of library law [7]. Currently, South Korea is one of the countries that have revised the library law the most. The public library law is China's first special library law, which was brewed in 2001 and comes into force in January 2018. During the period, it was submitted for official review-exposure review-draft-final legal text.

\subsection{Comprehensive Content, Detailed Regulations}

The library law of the U.S. covers almost all aspects of library work, including the establishment goal, resource construction, management institutions, departmental setup, operational research, funding subsidies, library staff, professional certification, storage libraries, government resource preservation, service and the establishment of library network. Some the U.S. state library act imposes minimum requirements on the personnel, service hours, and service content of libraries that are funded, and stipulates that libraries that fail to meet the minimum standards will be punished by cutting assistance. According to the Korean Libraries Act, only individuals with librarian qualifications became eligible for librarian positions and the occupation of "librarian" itself gained the status of a specialized profession. Utmost efforts were made to improve convenience and access for users with disabilities that were included in the "knowledge and information poor" category. Section 20 of the Japanese Library Law stipulates that the state government, in the context of the budget, may provide subsidies for the facilities and equipment required by the library and other necessary funds. It can be seen that the local government is the main input and manager of public library construction, that is, the local government bears most of the capital investment and daily management costs. The Chinese Public Library Law encourages and guides social forces to participate in the construction, service and management of public libraries, strengthens the protection of intellectual property rights, establishes the confidentiality and legitimacy of the contents of arc- 
hives and archives, and perfects the incentive mechanism for public library undertakings.

\section{Highlights on library law}

\subsection{The Simultaneous Development of Library Law and Library-Related Laws}

There are three main library laws in the U.S. at the federal level: Library Services Act, Library Services and Construction Law, and Library Services and Technology Law. At the local level, all 50 states and 1 district of the U.S. have their own library laws. In addition, the library industry associations in the U.S. are very developed, and have also made their regulations. Korean Libraries Act was enacted as an all-encompassing law, but since the School Library Promotion Act, University Library Promotion Act and other laws, based on the type of library, gained independence from the Libraries Act, the current situation cannot be regarded as stable. Japanese libraries have a complete system of laws and regulations, and the library law is the core. There are many other library-related laws and regulations. The legislative basis of Japanese Library Law is Education Basic Law, Social Education Law and School Education Law, and the latter often becomes the source and power of the former. Japan has basically realized the synchronous development of library law and related education law. The Chinese public library law has just been issued for more than a year, while China's other library-related legislation has been relatively mature, such as education law. The legislation in these related areas has not achieved synchronous and coordinated development.

\subsection{Legislate First, Then Continue to Improve}

The Korean Libraries Act was enacted in 1963 and underwent four complete revisions and enactment processes in 1987, 1991, 1994 and 2006. Based on the amendments of other laws and regulations, the Korean Libraries Act was partially amended over 20 times. Japan's Library Law has been amended more than 20 times, and it has been revised once every 3.2 years. The evolution of Japanese library law clearly shows that the construction of the library legislation is a process of gradual improvement. People can't hope that the Library Law or librar-related laws will be perfect from the beginning. When a country formulates and promulgates a law, it is inevitable that it will face the problem of constantly supplementing and perfecting existing laws with the development of the times and social progress. For library law, it is no exception. Paying attention to the legislative work of the Library Law, we also look at the revision work after the law is enacted, in order to ensure that the library law developed has a long-lasting vitality. Library legislation cannot be fixed once and for all. Timely revision is the proper meaning of library legislation.

\subsection{Guarantee the Financial Resources of the Library}

Stable and sufficient operating expenses are the premise to ensure the normal 
and orderly implementation of the library law. Therefore, when formulating library legislative provisions, the source of funding for the library is the most important content in the U.S., South Korea, Japan and China library laws. The provision of financial support for the library in the Federal Library Laws of the U.S. is the main content. At the same time, the legislation of each state also regulates the source, proportion and use of library funds. The main source of funding is the local taxation and state government financial assistance. Japan has designed the central government's "treasury grant" system in its library law. South Korea library law clearly proposed that the government provide funds to ensure the establishment and operation of libraries, and has established the Library Revitalization Foundation.

\subsection{Detailed Legislative Content}

The law contents in the U.S., South Korea and Japan are relatively detailed, the interpretation of each provision is also very detailed and specific, and the specific legal provisions are also clearly defined, which makes the legal provisions more operable. These law a cover almost all aspects of library work, including library setting goals, resource construction, management agencies, departmental setup, operational research, library staff, professional certification and government resources. Relatively speaking, many provisions of Chinese Public Library Law are relatively general, and the relevant provisions are not clear. For example, the qualifications for librarians: "library staff should have corresponding professional knowledge and skills". This expression is vague and difficult to implement in practice, which affects the legal effectiveness.

\section{The Suggestions on China's Library Law}

The Library Law of China was officially implemented on January 1, 2018, which is a new beginning for China. Through comparative analysis of the legislation of these national libraries, China can get the following references and inspirations.

\subsection{Improve the Legal and Regulatory System}

Japanese library legislation system has both special laws and related regulations, both industry standards and industry self-regulation. The library legislation system in the United States consists of three parts: the Federal Library Law, the State Library Law, and industry legislation. In addition to the library's basic law, state library law also includes library-related content in other laws and regulations. In contrast, China's library laws and regulations are relatively simple and lack systematic. We should formulate corresponding standards for specific areas to better meet the needs of all aspects of library management.

\subsection{Library Laws and Regulations Should Be Specific and Operable}

The legislative content of foreign libraries is more detailed, and the interpretation of each provision is also very detailed and specific, and the specific provi- 
sions of the law are more clear, which makes the legal provisions of strong operability. Relatively speaking, many provisions in the public library law of China are rather general, and the relevant provisions are not clear, such as the provisions on the qualifications of librarians: "library staff should have corresponding professional knowledge and skills". This kind of expression is vague and difficult to carry out in practice, which affects the exertion of the legal effect of library.

\subsection{Timely Revision}

Today's society is a fast-developing society. When a country formulates and promulgates a law, it is inevitable that it will face the problem of constantly supplementing and perfecting existing laws with the development of the times and social progress. It is no exception. China should treat the revision work after the library law is formulated as much as the legislative work of the library law, so as to ensure that the library law has long-term vitality. Chinese Library legislation cannot be changed once and for all, and the timely revision is the proper meaning of library legislation.

\section{Conclusion}

The formulation and promulgation of library law is an important prerequisite for the scientific and orderly development of the library. It is also an important symbol of the legalization of the national library industry. Looking at the experience of libraries in the world, most developed countries have carried out the legislative work of the library, and established a relatively complete library legal system. We should learn from the advanced legislative experience of these countries, formulate the library's special law, and revise it according to the actual situation, thus ensuring and promoting the healthy development of the library business.

\section{Conflicts of Interest}

The authors declare no conflicts of interest regarding the publication of this paper.

\section{References}

[1] Zhou, Z.Q. (2018) The Background and Prospect of the Promulgation of Public Library Law in China. Public Library Journal, 22, 4-10.

[2] Shen, X.J. and Li, D. (2018) Legislative Supplement of Public Library Law of the People's Republic of China (Part One). Library Development, No. 1, 7-18.

[3] Li, D. and Shen, X.J. (2018) Legislative Supplement of Public Library Law of the People's Republic of China (Part Two). Library Development, No. 2, 4-16.

[4] Zhao, J. and Wang, G.H. (2016) The Legislative Process, Characteristics and Enlightenment of Foreign Libraries. The Library Journal of Henan, No. 1, 73-75.

[5] Li, G.X. (2011) Japanese Public Library Legislation. Journal of Library Science in China, 51, 75-82.

[6] Ryu, H. (2017) A Comparative Research of Library Law in Korea and Japan: Focus- 
ing on the Enactment and Revision Processes. Journal of the Korean Library and Information Science Society, No. 1, 103-124.

[7] Zhao, F. (2013) Comparative Analysis of the Library Laws of China, the United States and Korea. History of Heilongjiang, No. 11, 103-124. 